\title{
The Soft Power of Teacher's Instructional Decision Making: An Empirical Study of 4 Chinese EFL Teachers and Native English Teachers
}

\author{
Youwen Zhang ${ }^{1} \&$ Zhihui Yang ${ }^{2}$ \\ ${ }^{1}$ School of Foreign Languages, Dongfang College, Zhejiang University of Finance and Economics, Haining, \\ Zhejiang Province, China \\ ${ }^{2}$ Labour Union Office, Dongfang College, Zhejiang University of Finance and Economics, Haining, Zhejiang \\ Province, China \\ Correspondence: Youwen Zhang, Dongfang College, Zhejiang University of Finance and Economics, Haining, \\ Zhejiang Province, China. E-mail: zyw12398@163.com
}

$\begin{array}{lc}\text { Received: January 8, } 2017 & \text { Accepted: January 24, } 2017 \quad \text { Online Published: January 27, } 2017 \\ \text { doi:10.5539/ells.v7n1p36 } & \text { URL: http://dx.doi.org/10.5539/ells.v7n1p36 }\end{array}$

\begin{abstract}
Beliefs, concepts and perceptions drive teachers' practices. This study reports a comparative enquiry into the soft power of decision making of two categories of teachers when approaching teaching in the language classroom. Decisions of tasks and participation structures teachers adopted in their instructions, and the underlying soft power of decision making in class are identified with reference to beliefs, knowledge, prior experiences and context. And it reveals that these teachers tend to capitalize on these theories eclectically, though they differ in the extent to which they stress one focus or another, and the logicality between teacher's soft power and instructional decision making exists and gives an insight into the critical issues related to future study.
\end{abstract}

Keywords: soft power, instructional, decision making, empirical study

\section{Introduction}

In 1990, Joseph Nye firstly proposed the term "soft power" in a series of papers, such as "The Nature of the Changing World Power" and "Soft Power", published in the magazines of "Foreign Policy" (Joseph, 1990a) and "Political Science Quarterly" (Joseph, 1990b). Since then, the research of "soft power" has gained a great response and initiated numerous debates.

While soft power mainly refers to a nation's, "guiding force, attractive force, and the power of emulation, which is an assimilation strength - the attractiveness of a national idea and the ability of the political orientation" (Joseph, 1990). In analyzing the connections between education, internalization and foreign policy, a high quality education sector is always considered as one of the important factors that contribute to a country's soft power (Wojciuk, Marta, \& Stormowska, 2015). Trilokekar (2010) also proposed that the foreign policy should contribute to the internationalization of higher education, and the international education is interpreted as a nation's soft power. And through the study of the OECD PISA in Switzerland and the US, Bieber \& Martens (2011) found this program can be rendered as a soft power in Education, and the extent of policy convergence depends on whether OECD can trigger convergence mechanisms in the respective country. While from the perspective of discourse analysis, Lomer (2016) represented the results of a textual analysis conducted on policy discourses on international students in the UK, and analyzed soft power as a policy rationale for international education. And Hayden (2015) explored how a comparative analysis of public diplomacy can account for differing articulations of soft power, and the kinds of tools that leverage communicative and cultural resources toward expected gains. Specifically from the language use, Rivas (2015) analyzed the use of the Spanish language as a retroactive strategy to promote the Spanish language in the United States as a way of extending its soft power. Under the macro background of education, internationalization and discourse are widespread in education and foreign policy, and also regarded as the soft power of a nation.

But at a small level, we use the concept of soft power of decision making for the teacher development in education, mainly referring to the ability of teachers exploring, determining, evaluating, and finally making the choice with regard to the teaching objectives and the teaching methods in the classroom teaching, which is a 
decision-making ability and classroom appeal of teachers in their instruction. Relying on culture, value, teacher knowledge and other intangible power, teachers exert an influence on teaching activities, life world, students, teaching mode, thinking mode and other aspects of instruction, which is specifically performed in four logical dimensions: the cognitive ability, judgment, the executive force and the creativity ingenuity. The decision-making soft power demonstrates the cognitive ability as the base, judgment as the core, the executive force as the performance, and the creativity ingenuity as the destination, which is unique, comprehensive, stable and developmental. The notion that decision making varies along the contextual and cognitive dimensions is widely shared in the literature (Kember, 1997; Samuelowicz \& Bain, 1992). However, this body of literature is limited by a lack of evidence regarding the precise nature and relationship between decision making and teachers' soft power, and how they operate in specific contexts to inform (or not) actual teaching practice. In this article, we elaborate on this body of research by using the empirical perspective, which emphasizes how teachers' soft power is largely shaped by individual teacher's perception of the constraints and affordances related to a specific instructional decisions or task situation, which then penetrates into the logicality of the instructional decision making and teachers' soft power.

The article addresses the following questions:

- What are two groups of teachers' decisions of tasks and participation structure in terms of specific instructional activities in their teaching?

- How do teachers' beliefs, knowledge and experience affect their instructional decisions in the teaching practice?

- How do Chinese EFL teachers and native English teachers perceive their instructional context?

-What, if any, underlying logic relation exists for teacher's soft power and instructional decision making?

In exploring these phenomena among a sample of 4 Chinese EFL teachers and native English teachers in two public research universities in China, we try to find out and analyze the similarities and differences between two categories of teachers' decision practice, which will surely give an insight into the influencing factors and the mechanism of instructional decision making, the underlying logicality of teacher's soft power and instructional decision making, and provide some ideas for our teacher development.

\section{Methods}

\subsection{Participants}

The case focuses on two Chinese EFL teachers and two native English teachers at two public research universities in China who taught the same level of students (second year students), which provided a paralleled basis for comparison in terms of students' variables within and across two institutions. For the analyses of four instructors' decision-making processes, we also use a concurrent mixed methods design that includes both interviews and classroom observations (Tashakkori \& Teddlie, 2002).

\subsection{Instruments}

The design for the study is a qualitative case study, which is an intensive analysis of a single bounded unit (Yin, 2008). The data collected in this study includes questionnaire, interviews and classroom observations with each respondent. An approximately one-hour pre-observation interview with each teacher was conducted in order to establish a profile of his educational background, reasons for being a teacher, experience of teaching, general views about FL teaching. The researcher conceived of the interview as a semi-structured conversation (Kvale, 1996) that focused on several particular themes without being rigidly structured. And each of the four teachers was observed teaching four consecutive one-and-a-half-hour classes. The observation encompassed complete lesson units which were part of regularly scheduled classes, as recommended by Van Lier (1988). These classes were audio-taped, and field notes were taken during the observation. Following each lesson, there was a post-observation interview with the teacher. The researcher presented them with some "key instructional episodes"-classroom incidents that generated questions about the rationale for the teacher's approach to the teaching (Borg, 1998). The kinds of interactive decisions made by two categories of teachers were identified by observing and interviewing them immediately after each class. In this research, one dimension of teacher's decision making practice, i.e., tasks and participation structure, deserves to be further elaborated. Teachers were asked to analyze their lesson tasks in terms of participation structure and language focus on task grids (see figure 1). Smith (1996) reported that, in analyzing task implementation, participation structure and language focus (accuracy and fluency) were considered as two focal dimensions of the task grid emerged from the L2 literature. The task grid required teachers to indicate two features of their lesson tasks: whether the task focused mainly on accuracy or fluency language learning objectives, and whether the task was primarily teacher-centered or student-centered (the participation structure). 


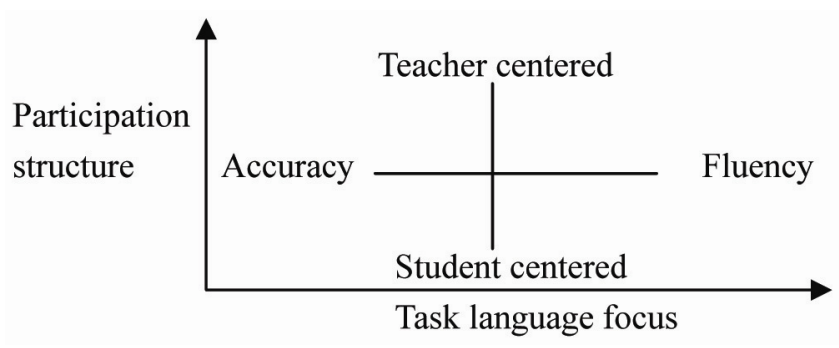

Figure 1. Task grid (from Smith, 1996)

One of the central units of classroom management and organization was involved in participation structures. The term participation structure refers to the way in which students are organized for particular tasks: as a whole class, in small groups, in pairs, or as individuals (Smith, 1996). In this study, both groups of teachers adopted whole-class and small-group or pair activities, while they did differ in the extent to which each emphasized one focus or another.

\section{Results}

Teachers' decision-making soft power is, to a large extent, demonstrated in the process of teaching practice, the research of instructional decision-making soft power is closely related to teacher's cognition, and the use of cognition to explore the soft power of instructional decision making is based on the concept of teaching as a complex mental process, it is affected by a teacher's mental and information processing capabilities (Shavelson \& Stern, 1981). Teachers' beliefs, thinking, judgment can guide their teaching behavior. Teacher cognition mainly includes teachers' knowledge, belief and thinking (Calderhead, 1996). The research of teachers' decision-making soft power mainly involves investigating teachers' beliefs, judgment, planning and teaching process (Clark \& Peterson, 1986; Shavelson \& Stern, 1981).

We analyzed the data for this study in two stages. First, we analyzed the planning or instructional practices of four instructors to investigate the specific mechanisms of teachers' decision making in implementing their instructional decisions, which is the core of teacher's decision-making soft power. Second, we analyzed all 50 interview transcripts to identify teacher beliefs, teacher knowledge, perceptions of the instructional contexts and any underlying logicality by which soft power influenced (or not) their teaching practices.

\subsection{Teachers' Decisions of Tasks and Participation Structure: Three Cases of Real-World Practice}

An important manifestation of teacher's executive force lies in the classroom organization and the implementation of teaching tasks. This is also a concentrated expression of decision-making soft power. To examine teacher's instructional tasks and participation structure in real-world practice, in-depth descriptions of the decision-making processes of four faculties are presented in this section. Teacher's executive ability is largely demonstrated in the process of teacher's implementing their instructional decisions. In addition, I also explore the degree to which other cognitive schemata (e.g., goals), personal attributes, perceived affordances, and course content influence teachers' decision practice in the classroom instruction.

\section{Mr. David}

The first case described the instructional decision making of Mr. David (pseudonym), a full-time native English lecturer at Institution A. At the time of data collection, Mr. David was teaching the third quarter in the business management. In the observed class, Mr. David began by outlining the two main goals for the day's class: to understand the business negotiation, and the negotiation strategies. He then demonstrated the principles of using these business strategies, and discussed these strategies used in appropriate context. The remainder of the class followed this pattern of teaching behaviors: a detailed interpretation to the reading materials through diagram and pictures, demonstration of these materials on the chalkboard, and then a series of questions were posed to seek new information. The participation structure of the class switched from whole-class lecture to team work, and he uses the process approach for developing speaking skills. In response to the question regarding his course planning, Mr. David expressed that he was more concerned about the content-focused planning and tried to promote a communicative language use (defined in this study as fluency-focused).

For David, the way he structured his class related to his underlying beliefs about how language should be taught and how classroom instruction arranged. The lecture part just "gives them (students) foundation for the other part of the class. The other part of the class is team work, they will interact, and collaborate on learning." Whether in 
lecture part or team work, he claimed to teach communicatively, "taking the concepts and applying them" was his strategy and aim of concentrating on language use in the classroom teaching.

\section{Ms. Shen}

The second analysis features Ms. Shen, who was a full-time lecturer in the English Department. She had been at Institution A for over 8 years and was teaching a junior level intensive reading course. In response to the question about classroom instruction, Ms. Shen stated:

You know, all my students will attend Band Four exam this semester, which always puts me under pressure. It is certain that my teaching will revolve around the textbook and teaching program, the exam is purposeful for the apprehension of vocabulary and grammar rules rather the communicative interaction. Surely I will take the student's oral ability into account as far as possible, so I do some group discussion in my teaching. However, the urgent job at present is considering how to make the students pass the examination.

This statement clearly indicates that Ms. Shen held the variability belief about classroom instruction. This teaching view was characterized as a "examination orientation" in that it placed the examination and the implementation of teaching materials at the center of considerations about instruction. And the teacher's perspective emphasized the instructor's considerations for examination and material over any thoughts about students' abilities or learning styles.

For the observed class, Ms. Shen planned on discussing food style and eating habits. In terms of teaching methods, she planned to lecture as an introduction to the material, to "frame" the class period, and to introduce new content. Ms. Shen also planned on using her traveling story as a precursor to small group discussions, show Power Point slides, and pose several questions to students. The next stage of the lesson switched to whole-class lecture, and the teaching was mainly attached to the textbook, generally, she analyzed it sentence by sentence, occasionally students would be asked to make a sentence with the word she illustrated or answer some questions. The remaining session maintained almost the same teaching mode. In the observed class, Ms. Shen exhibited a variety of teaching methods including lecturing, question-asking, small group work and illustrations.

\section{Ms. Tan and Mr. Jon}

Another Chinese EFL teacher Ms. Tan ever co-taught with Jon in the literature class, both working in Institution B for over 5 years. Ms. Tan's way of structuring the lesson was quite different from Jon's, and they also had much controversy on many issues when co-teaching, even though they both agreed that their teaching benefited a lot from each other and different teaching styles were definitely conducive to students' learning.

In the observed class, Ms. Tan wanted to introduce transcendentalism in her class, she lectured at the chalkboard, and demonstrated the background information of the book Self-reliance. The remainder of the class followed this pattern of teaching behaviors: lecturing at the chalkboard, demonstration, and posing display questions seeking new information. Her opinion of the teacher-centered approach to teaching and perception of Jon's approach to literature teaching provided an in-depth insight into the inner thought of her way of structuring the class:

It is markedly less efficient when I employ the method of group discussion in my lesson...however, I am confined with the teaching guideline, you know, I have to adhere to the guideline. It is impossible for me to just obtain some complementary materials without taking pedagogic knowledge content into account. Right? I have to consider how much content I impart to them in each session.

When Jon's class was mentioned that students might be more motivated to learn, her answer was thought-provoking:

I'm inclined to cover as much content as possible in restricted time. The more I offer, the more students will obtain, the better I feel in my mind. As for the students' feeling, I haven' $t$ thought too much. The students in Jon's class will respond actively to deliver their opinion; yet I just seek a kind of balance in my conscience.

While in Jon's class, after over 30 minutes' introduction of the book Self-reliance and the author's philosophic thoughts, students were engaged in small group discussion, and he himself participated in each group's discussion, finally each group would be assigned to give a presentation. When asked to interpret his way of structuring the class, Mr. Jon clearly indicated that learning is dependent on students actively constructing their own unique understanding of course material. In several cases, he used "construct" to describe the learning process.

Totally speaking, native English teachers structured their classroom activities eclectically, i.e., they used both the whole-class and small-group activities in complementing their tasks. Through the small-group activities employed in the class, they built a cohesion between the small-group activities and the lecture part. And that is 
also an active construction. Two native English teachers specifically referenced constructivist learning theories. This belief differs from the practice belief in articulating the type of reasoning that best facilitates learning, and not just the type of learning activity students should engage in.

One important element of teacher's decision making is to cultivate innovative thinking, which is largely concerned with active construction, an important idea underpinning this philosophy is that students do not rely on the instructor's formulation of a concept or the textbook. And as one faculty noted, "successful students reformulate it (course material) in their own terms." In the process of meaning construction, students are open to the discussion of course materials and the formation of mainstream ideology, they may establish their own behavior norms and value system in these learning practice.

While Chinese EFL teacher's lessons observed was mainly conducted in a whole-class model though some of them may offer a few seatwork activities to try to enhance the quality of learning time. However, methods of carrying out most of the group activities were routinely followed as a cookbook of behaviors. It seemed that the group discussion was processed for the sake of discussion. Though teachers in their planning were intended to make their classroom instruction lively, dynamic and productive, the actual learning in their classroom was relatively lacking in communication and meaning construction. Yet the mode of teacher-centered classroom instruction was typically Chinese EFL teachers' pedagogic decision even though some teachers would additionally use some small-group activities in their lesson. It is obvious that teacher's approach to instruction is inevitably a compromise of "teacher's vision of teaching" (Johnson, 1996) and various teaching contexts. Within this framework the teacher monitored the whole classroom instruction and the students could hardly construct their own meanings except following the flow of instruction.

The ability of teacher's decision making is largely determined by teacher's inner beliefs, knowledge and creativity ingenuity, and particularly affected by the specific context in which the problem is being solved and the corresponding strategies adopted in complex environments. By filtering information, structuring or defining tasks and directing corresponding actions, the teacher's educational philosophy, cognitive ability and judgment can play an influential role in the process of instructional decision making.

\subsection{Teacher's Beliefs and Knowledge in Their Instructional Decisions}

Teaching is a complex process which can be conceptualized in a number of different ways. Traditionally, language teaching is described in terms of teachers' action and behavior in the classroom. To understand the behavior of teachers in teaching, we must examine the beliefs and thinking processes underlying teachers' classroom actions and behaviors. This view is based on the assumption that the teacher's behavior is a reflection of their knowledge and beliefs, teacher knowledge and teacher thought provides a potential framework or schema that determines the teacher's classroom behavior.

Teaching involves a cognitive, an emotional and a behavioral dimension (Clark \& Peterson, 1986; Lynch, 1989). Teacher cognition includes the knowledge, beliefs, and thinking of teachers (Calderhead, 1996). Research on teacher cognition made the basic assumption that teachers' thoughts, judgements and decisions guide their teaching behavior. Teacher knowledge and teacher beliefs have been distinguished in an extensive literature (Fenstermacher, 1994; Richardson, 1996). And different categories of teacher knowledge have been identified or described, including subject or content knowledge (Grossman, 1990), pedagogical content knowledge (Gudmundsdottir, 1991; Shulman, 1987) etc., and they basically encompass such elements as past experience, instructional and classroom management and context-specific knowledge etc., and teachers accumulate these teaching information with practice. While teachers' belief systems are based on the goal, value and thought system of teachers, and they are related to teaching content, teaching process and teachers' working environment.

Teachers' knowledge and beliefs about language learning and teaching appear to be the critical factor influencing the soft power of teacher's decisions making. The central role that beliefs and knowledge play is evident not only in how these teachers organized and planned their lessons, but more significantly in their approaches to classroom instruction. While teacher decisions are guided by a coherent set of personal beliefs and a repertoire of first-hand experience, and teacher use these theories eclectically, that is, individual teacher decisions do not wholly abide by one or the other, but in fact a combination of these beliefs and experience. The coexistence of a high degree of lecturing and high proportions of interactive teaching techniques and a range of student cognitive engagement suggests that it may not be the case that faculty who value students' construction of meaning do not lecture and that lecturing does not automatically translate into unsatisfactory or inadequately engaging instruction. Native English teachers who are more communication-orientated also adopt the whole-class instruction strategy in their classrooms, while some Chinese EFL teachers utilize the small-group activities as well, despite they consider the grammar and accuracy to be a priority in instructional goal. 


\subsection{Prior Experience in Teacher's Classroom Decision Making}

Teachers' prior experience is certainly another important factor which strongly affects the soft power of teacher's decision making. As Lortie (1975) has demonstrated that the teacher's models of teaching are strongly affected by their own experience as students or teachers. This, in Chinese school system, generally means a heavy emphasis on textbooks, examination preparation, and an expectation of teacher control in the classroom teaching. Their pedagogical decisions would therefore be likely to be affected by their accumulated learning or teaching experience.

Native teachers' vast experience as learners was established in their own culture. Their peculiar experiential knowledge immersed in their own culture evidently shaped what they did in the language classroom and was in turn shaped by their current teaching experience. Then their instructional decisions were largely different from those of Chinese EFL teachers', though they might modify some of their teaching beliefs in response to the teaching contexts in China.

\subsection{Perceptions of the Instructional Context in Decision Making}

A core idea from these teaching practice is that teachers do not simply enact curriculum in the classroom but instead are complex decision-makers whose problem-solving capabilities are shaped by a combination of the characteristics (and constraints) of cognition as well as features of the instructional situation (Lee \& Porter, 1990; Shavelson \& Stern, 1981). It is recognized that teacher decision making is not immune from the effects of contextual factors, and many of teachers' instructional decisions are made on the basis of teacher's perceptions of instructional context. A representative contextual factor in teacher decision-making mechanism is the organizational factors (i.e., the structure of an organization and its socio-cultural characteristics), especially the organizational factors within the institutions of higher education. Matthew (2012) stated that organizational factors refer to the organizational structure and its social and cultural characteristics in the institutions of higher education. They would affect the teaching practice to a great extent (such as curriculum planning, pedagogical technique selection, etc.). Studies have shown that organizational factors are diverse, including governance systems and workload policies and departmental traditions etc., these organizational factors do not exist independently, but interact with individual faculty to determine and shape individual faculty's teaching practice. Therefore, individual faculty actively negotiate, or make sense of, these contextual factors in customized ways as they make decisions about teaching (Henderson \& Dancy, 2007).

Organizational factors will absolutely affect the way teachers manage their teaching and teachers' decision-making paths alike. Both institutions provide explicit course guideline and prescribed teaching materials for Chinese EFL teachers, and they are always under the pressure of examination preparation, in the vast majority of the classes observed, the teachers dominated the classrooms, and their strong adherence to a prescribed lesson material helped them to ensure students' understanding, and to maintain rapport and control.

In each institution, for native English teachers, they are a little bit special faculty. They work in a relatively free setting and they can, to a great extent, decide on their teaching materials and the way how to structure their classes. In a way, institutional and disciplinary variation will echo on faculty approaches to teaching, and teachers' perceptions of the instructional context could alter teaching approaches. The different influence that the administrative factors exert on native English teachers and Chinese EFL teachers may differ in how to approach their instruction, and affect the soft power of their pedagogic decisions. And the ability of teachers' decision making is simultaneously affected by the specific context in which they are addressed and the corresponding strategies they employ in different complex environments. This line of inquiry will also give an insight into how the context influences the relationship between thought and action.

\subsection{The Logical Relation between Teacher's Soft Power and Instructional Decision Making}

In teaching practice, the accumulation of language teachers' soft power is complementary to the classroom decision-making ability. From four dimensions of soft power, the logical relationship between teacher's soft power construction and decision-making practice is mainly embodied in four aspects: Firstly, cognitive ability as the logical foundation of language teachers' soft power, is the internal foundation to generate classroom decision-making practice. Cognitive ability refers to the ability of the human brain to process, store and extract information; perception, memory, attention, thought and imagination are all recognized as cognitive abilities. The cognitive ability of language teachers is the basic factor to realize teachers' decision-making soft power.

Secondly, as the core element of the soft power of language teachers, judgment is the logic focus for generating the core of decision-making practice. Judgment mainly refers to the teacher's understanding and recognition of the classroom events and their coping strategies in the classroom teaching practice. Generally, judgment is the 
determinant of what attitude towards reality to take and what kind of way of behavior to show. Judgment is the ability to express their values through events in the form of choice and selection. Judgment is a prerequisite for teachers to make instructional decisions, which not only affects the value orientation of decision-making events of language teachers, but also determines the decision-making ability of language teachers.

Thirdly, executive force, as the external manifestation of language teachers' soft power, is the external basis for generating the dominant core of classroom decision-making practice. As a kind of objective reflection of language teachers' soft power in instructional decision-making, executive force is a three-dimensional unification of teaching practice, teaching thought and teaching competence. It is about the positive interaction between teachers and students, the realization of teaching thought and teaching belief, simultaneously extending to the benign interaction between teaching and learning, the achievement of teaching objectives and teaching plan. Executive force includes the willingness to complete the task, the ability to complete the task and the degree of completion of the task. Executive force is the key to transforming teaching decisions, plans, and goals into benefits and outcomes.

Fourthly, creativity ingenuity, as the value home of language teachers' soft power, is the final embodiment of the dominant core of classroom decision-making practice. Its main component is divergent thinking, that is, an unoriented and unconstrained way of thinking from the known world to exploring the unknown. Creativity ingenuity is the logical destination of the cognitive ability, judgment and executive force generated by the language teacher in the classroom decision-making practice. Its essence is a kind of practical influence and innovative ability, which is embodied as a guiding force in the formation of mainstream ideology, such as the behavior norms and the value system, and as the management capability and innovation in teaching practice, which is also the final form of expression in the core of language teachers teaching decision-making practice.

\section{Conclusions}

Research into teachers' beliefs, knowledge, prior experience, perceptions, and (personal) practical theories in classroom decision making is grounded in the understanding that these concepts drive teachers' practices, and these practices demonstrate the soft power of instructional decisions. And teachers' behavior in classrooms, in turn, affects the beliefs teachers hold, their perceptions and judgments in decision making. Based on the findings presented in this article, we strive to achieve more research results and hope to provide some suggestions and guidance for our language teachers and policy makers. Fruitful avenues for future research that address the relationship among cognition, context, practice and soft power are apparent. First, future research should explore in greater detail how cognition, context and experience may act as a framing device for language teachers in naturalistic decision making. Second, research focusing on how beliefs, concepts and context may influence the soft power of decision making through unconscious or automatic mechanisms should be conducted. Finally, research examining the role of factors known to influence teachers' decision making, in how faculty construct the instructional practice would shed important light on the role of individual characteristics and contextual factors on the mechanisms of instructional decision making. In any case, a more multi-dimensional and nuanced approach to the study of faculty decision making in classroom is warranted, and promises to shed light on critical issues related to educational improvement.

\section{Acknowledgements}

This research is funded by the Chinese Ministry of Education Humanities and Social Sciences Research Fund Project in the year 2013 "A Comparative Study of Instructional Decision Making between Chinese EFL Teachers and Native English teachers" (13YJC740142).

\section{References}

Bieber, T., \& Martens, K. (2011). The OECD PISA Study as a Soft Power in Education? Lessons from Switzerland and the US. European Journal of Education, 46(1), 101-116. https://doi.org/10.1111/j.1465-3435.2010.01462.x

Borg, S. (1998). Teacher's pedagogic systems and grammar teaching: A qualitative study. TESOL Quarterly, 32(1), 9-38. https://doi.org/10.2307/3587900

Calderhead, J. (1996). Teachers: Beliefs and knowledge. In D. C. Berliner \& R. C. Calfee (Eds.), Handbook of Educational Psychology (pp. 709-725). New York: Macmillan.

Clark, C. M., \& Peterson, P. L. (1986). Teachers' Thought Processes. In M. C. Wittrock (Ed.), Handbook of Research on Teaching (3rd ed., pp. 255-296). New York: Macmillan.

Fenstermacher, G. D. (1994). The Knower and the Known: The Nature of Knowledge in Research on Teaching. 
In L. Darling-Hammond (Ed.), Review of Research in Education, 20, 3-56. Washington, D.C: American Educational Research Association. https://doi.org/10.2307/1167381

Grossman, P. L. (1990). A Tale of Two Hamlets. In the Making of a Teacher: Teacher Knowledge and Teacher Education (pp. 1-18). New York: Teachers College Press.

Gudmundsdottir, S. (1991). Ways of Seeing are Ways of Knowing. The Pedagogical Content Knowledge of an Expert English Teacher. Journal of Curriculum Studies, 23, 409-421. https://doi.org/10.1080/0022027910230503

Henderson, C., \& Dancy, M. H. (2007). Barriers to the use of research-based instructional strategies: The influence of both individual and situational characteristics. Physical Review: Special Topics Physics Education Research, 1-14. https://doi.org/10.1103/physrevstper.3.020102

Johnson, K. E. (1996). The Vision versus the Reality: The Tensions of the TESOL Practicum. In D. Freeman \& J. C. Richards (Eds.), Teacher Learning in Language Teaching (pp. 30-49). Cambridge: Cambridge University Press.

Joseph, S. N. (1990a). Soft Power. Foreign Policy, 80, 153-171.

Joseph, S. N. (1990b). The Nature of the Changing World Power. Political Science Quarterly, 47-51.

Kember, D. A. (1997). Reconceptualisation of the Research into University Academics Conceptions of Teaching. Learning and Instruction, 7, 255-275. https://doi.org/10.1016/S0959-4752(96)00028-X

Kvale, S. (1996). Interviews: An Introduction to Qualitative Research Interviewing. Thousands Oaks, CA: Sage.

Lee, O., \& Porter, A. (1990). Bounded Rationality in Classroom Teaching. Educational Psychologist, 25(2), 159-171. https://doi.org/10.1207/s15326985ep2502_4

Lomer, S. (2016). Soft Power as a Policy Rationale for International Education in the UK: a Critical Analysis. Higher Education, 1-18. https://doi.org/10.1007/s10734-016-0060-6

Lortie, D. (1975). Schoolteacher: A Sociological Study. Chicago: University of Chicago Press.

Lynch, T. (1989). Researching Teachers: Behavior and Belief. In C. Brumfit \& R. Mitchel (Eds.), Research in the Language Classroom. Modern English Publications in association with The British Council.

Matthew, T. H. (2012). Organizational Factors and Instructional Decision-Making: A Cognitive Perspective. The Review of Higher Education, 207-235.

Richard, J. C., \& Lockhart, C. (1996). Reflective Teaching in Second Language Classrooms. Cambridge: Cambridge University Press.

Richardson, V. (1996). The Role of Attitudes and Beliefs in Learning to Teach. In J. Sikula (Ed.), Handbook of Research on Teacher Education (pp. 102-119). New York: Simon \& Schuster.

Rivas, C. V. (2015). The Use of the Spanish Language as a Cultural Diplomacy Strategy for Extending Mexico's Soft Power in the United States. Place Branding and Public Diplomacy, 139-147. https://doi.org/10.1057/pb.2014.33

Samuelowicz, K., \& Bain, J. D. (1992). Conceptions of Teaching Held by Academic Teachers. Higher Education, 24, 93-111. https://doi.org/10.1007/BF00138620

Shavelson, R. J., \& Stern, P. (1981). Research on Teachers' Pedagogical Thoughts, Judgments, Decisions, and Behaviors. Review of Educational Research, 51(4), 455-498. https://doi.org/10.3102/00346543051004455

Shulman, L. S. (1987). Knowledge and Teaching: Foundations of the New Reform. Harvard Educational Review, 57, 1-22. https://doi.org/10.17763/haer.57.1.j463w79r56455411

Smith, D. B. (1996). Teacher Decision Making in ESL Classroom. In D. Freeman \& J. C. Richards (Eds.), Teacher Learning in Language Teaching (pp. 197-216). Cambridge: Cambridge University Press.

Tashakkori, A., \& Teddlie, C. B. (2002). Handbook of Mixed Methods Social and Behavioral Research. Thousand Oaks, CA: Sage.

Trilokekar, R. D. (2010). International Education as Soft Power? The Contributions and Challenges of Canadian Foreign Policy to the Internationalization of Higher Education. Higher Education, 59(2), 131-147. https://doi.org/10.1007/s10734-009-9240-y

Van Lier, L. (1998). The Classroom and the Language Learner: Ethnography and Second Language Classroom research. London: Longman. 
Wojciuk, A., Marta, M., \& Stormowska, M. (2015). Education as a Source and Tool of Soft Power in International Relations. European Political Science, 14, 299-309. https://doi.org/10.1057/eps.2015.25

Yin, R. (2008). Case Study Research: Design and Methods (4th ed.). Thousand Oaks, CA: Sage.

\section{Copyrights}

Copyright for this article is retained by the author(s), with first publication rights granted to the journal.

This is an open-access article distributed under the terms and conditions of the Creative Commons Attribution license (http://creativecommons.org/licenses/by/4.0/). 